\title{
Lectin histochemistry and ultrastructure of rainbow trout Oncorhynchus mykiss kidneys affected by proliferative kidney disease
}

\author{
Massimo Castagnaro ${ }^{1}$, Mercedes Marin ${ }^{2}$, Claudio Ghittino ${ }^{2}$, Ronald P. Hedrick ${ }^{3}$ \\ ${ }^{1}$ Dipartimento di Patologia Animale, Via Nizza 52, I-10126, Torino, Italy \\ ${ }^{2}$ Istituto Zooprofilattico Sperimentale del Piemonte, Liguria e Valle D'Aosta, Via Bologna 148, Torino, Italy \\ ${ }^{3}$ Department of Medicine, School of Veterinary Medicine, University of California, Davis, California 95616, USA
}

\begin{abstract}
Eleven biotinylated lectins and the avidin-biotin-peroxidase system (ABC) were used to detect and localize specific carbohydrate residues of the primary (PKX-PCs) and daughter cells (PKKDCs) of the PKX myxosporean, lymphocytes, macrophages and renal tubular epithelial cells of rainbow trout Oncorhynchus mykiss affected by proliferative kidney disease (PKD). Electron microscopy revealed the presence of the typical PKX-PCs and PKX-DCs in the renal interstitium, between tubular epithelial cells, and of some intraluminal forms, and showed that the principal inflammatory cells surrounding PKX were lymphocytes and macrophages. The latter were most often elongated and closely adherent to the PKX cell surface. Except Ulex europaeus agglutinin-I, which was always negative, all the lectins exhibited a specific binding pattern on the cells examined. Concanavalia ensiformis (Con-A), Lycopersicon esculentum (LEA), Lens culinaris (LCA), Phytolacca americana (PWM), Ricinus communis (RCA-I), and Triticum vulgaris (WGA) agglutinins stained PKX cells, macrophages, lymphocytes, and tubular epithelial cells. However, PKX-DCs and intraluminal forms were less intensely stained than PKX-PCs with Con-A, LEA, PWM, and RCA-I, and receptors for LCA and WGA were not detected. In the renal interstitium, Arachis hypogea agglutinin (PNA) bound strongly to the cytoplasm of macrophages but much less intensely to PKX-PCs and some lymphocytes. Griffonia simplicifolia agglutinin-I (GS-I) stained intensely the cytoplasm of PKX-PCs and the luminal surface of tubular epithelial cells whereas a weak reaction was present in the cytoplasm of PKX-DCs and intraluminal forms. Dolichos biflorus and Glycine max agglutinins stained PKX-PCs weakly and inconsistently. These observations reveal some differences in glycoconjugate contents between PKXPCs and PKX-DCs and provide preliminary data on their carbohydrate components. The lectin PNA could be an important tool to evaluate the macrophage reaction during PKD and other infections of fishes. Finally, the elective staining of GS-I for PKX cells may be used in quantitative determinations by light microscopy of the degree of PKX infection, and for detection of the myxosporean when in low numbers. In addition, staining of PKX with lectins may allow recognition of forms of the parasites presently not well known, such as the early infective stages.
\end{abstract}

\section{INTRODUCTION}

Proliferative kidney disease (PKD) is caused by a protozoan of uncertain classification (PKX) and is characterized by a chronic inflammation of the kidney. Although several salmonid species may be affected by PKD (Clifton-Hadley et al. 1984, Hedrick et al. 1984, Hedrick et al. 1985), the disease has been reported most often in rainbow trout Oncorhynchus mykiss (formerly Salmo gairdnen) (Clifton-Hadley et al. 1984).

The causative agent of the disease was initially believed to be an amoeba (Plehn 1924, Ghittino et al. 1977, Ferguson \& Needham 1978). Later, based on internal cleavage, presence of 'haplosporosomes', and an amorphous cell wall, investigators suggested that PKX might be a haplosporidian (Seagrave et al. 1980, Ghittino 1984). However, a detailed description of PKX in the renal interstitium and lumina of the tubules of rainbow trout with PKD by Kent \& Hedrick (1986) indicated that PKX is a member of the phylum Myxozoa and most likely a Sphaerospora sp. (Hedrick et al. 1987).

Histologically, the identification of PKX can be performed on kidney sections stained with hematoxylin \& eosin, Prices's Giemsa methods or by wet mounts examined by brightfield or phase contrast microscopy 
(Kent \& Hedrick 1986). However confusion with macrophages can occur, particularly when the staining between cytoplasm and nuclear material is not differential. Furthermore, the presence of degenerative changes in normal cells may interfere with or preclude the diagnosis of PKX (Hedrick et al. 1986). The absence of a specific staining method for PKX therefore, makes quantitative determination of the myxosporean in tissue sections time-consuming and uncertain.

The initial cellular response to $\mathrm{PKX}$ is the proliferation of hemopoietic cells in the renal interstitium (Clifton-Hadley et al. 1985). Later in infection, the parasites are found mainly in the renal interstitium and often surrounded by macrophages and lymphocytes (Ghittino 1984, Kent \& Hedrick 1986, Clifton-Hadley et al. 1987. McConnell et al. 1988). Although this strong immunological reaction is thought to provide immunity to fishes recovering from infection, it also contributes to the mortality associated with PKD (Klontz et al. 1986). In contrast, other studies have indicated that macrophages are the cells which effectively interrupt the development of PKX (MacConnell et al. 1988). Hence, in order to understand the specific role of lymphocytes and macrophages in the pathogenesis of PKD, it would be important to better characterize the inflammatory cell population in PKD kidney.

Lectins are sugar-binding proteins and glycoproteins of non-immune origin, which agglutinate cells or precipitate glycoconjugates with saccharides of appropriate complementarity (Goldstein et al. 1980). For this reason, they have been extensively used to study the biology of carbohydrates in various in vitro and in vivo systems (Goldstein \& Hayes 1978, Lis \& Sharon 1984).

Lectins are currently used by histochemical methods to determine specific saccharide components of cells in situ (Alroy et al. 1984). In human and animal biology, lectins conjugated with various visualants have been used to localize and characterize lectin receptors during normal and pathologic conditions of several tissues (Damjanov 1987, Danguy et al. 1988)

In parasitic diseases of different organisms, lectin histochemistry has been employed to identify and characterize several metazoan and protozoan parasites (de Miranda Santos \& Pereira 1984, Ward et al. 1985, Cushion et al. 1988, Leducq et al. 1988, Zelck \& Becker 1990). Furthermore, some lectins have been shown to be reliable markers for the lymphoid and non-lymphoid cells of the immune system (Howard \& Batsakis 1982, Frydecka et al. 1987, Heegaard \& Müller 1988, Turnwald et al. 1988, Nagi \& Babiuk 1989).

In this study we attempted to identify the non-reducing terminal and some internal carbohydrate residues of PKX glycoconjugates, and to characterize the lectin receptors of macrophages and lymphocytes. We used 11 different biotinylated lectins and the avidin-biotinperoxidase complex as applied to tissue section from the kidney of rainbow trout with by PKD. Ultrastructural studies were also included to assist in the identification of PKX and associated inflammatory cells.

\section{MATERIALS AND METHODS}

Kidney tissue was collected from five 9-mo-old (mean weight $=150 \mathrm{~g}$ ) rainbow trout Oncorhynchus mykiss (formerly Salmo gairdnen) with gross signs of PKD. For histological diagnosis of PKD, formalin-fixed paraffin-embedded $4 \mu \mathrm{m}$ sections were stained with hematoxylin and eosin, Giemsa and PAS methods.

Control kidney sections taken from 3 normal 15-moold rainbow trout (mean weight $=250 \mathrm{~g}$ ) were also

Table 1. Lectins used in the study

\begin{tabular}{|c|c|c|c|}
\hline Lectin origin & Acronym & Concentration used $\left(\mu \mathrm{g} \mathrm{ml}^{-1}\right)$ & Major sugar specification ${ }^{a}$ \\
\hline Arachis hypogea & PNA & 20 & Gal- $\beta-(1-3)-G a l N A C$ \\
\hline Concanavalia ensiformis & Con-A & 10 & $\alpha-D-M a n>\alpha-D-G l c$ \\
\hline Dolichos biflorus & DBA & 20 & $(\alpha-D-G a I N A c)$ \\
\hline Glycine max & SBA & 20 & D-GalNAC > D-Gal \\
\hline Griffonia simplicifolia & GS-I & 50 & $\alpha-D-G a l$ \\
\hline Lens culinaris & LCA & 20 & $\alpha-D-M a n>\alpha-D-G I C$ \\
\hline Lycopersicon esculentum & LEA & 50 & (GlcNAC) \\
\hline Phytolacca americana & PWM & 50 & (GLCNAC) \\
\hline Ricinus communis & RCA-I & 50 & $\beta-\mathrm{D}-\mathrm{Gal}$ \\
\hline Triticum vulgaris & WGA & 50 & $(\beta-$ GlcNAc $)>$ NeuNac \\
\hline Ulex europaeus & UEA-I & 20 & $\alpha$-L-fucose \\
\hline
\end{tabular}


included. Kidney sections were deparaffinized and hydrated, and endogenous peroxidase activity was blocked by incubating tissue sections in $3 \%$ hydrogen peroxide in water solution at $40^{\circ} \mathrm{C}$. Tissue sections were immersed in $0.1 \%$ trypsin-calcium chloride solution, and incubated for $30 \mathrm{~min}$ at $37^{\circ} \mathrm{C}$.

Kidney sections were incubated with 11 different biotinylated lectins (Sigma Chemical Co., St Louis, $\mathrm{MO}$, USA) for $1 \mathrm{~h}$ at $20^{\circ} \mathrm{C}$. The lectins used, their acronyms, the concentrations used, and the major sugar specification are listed in Table 1.

The sections were incubated with the avidin-biotinperoxidase complex (ABC) (Vector Lab., Burlingame, CA, USA) for $30 \mathrm{~min}$ at $20^{\circ} \mathrm{C}$. The sections were covered with a solution of $0.01 \%$ diaminobenzidine and $3 \%$ hydrogen peroxide for $5 \mathrm{~min}$. The golden dark brown 3'3-diaminobenzidine tetrahydrochloridehydrogen peroxide product was used to reveal positive structures. An equal amount of each lectin and $0.2 \mathrm{M}$ of their corresponding blocking sugar was incubated for $1 \mathrm{~h}$ at $20^{\circ} \mathrm{C}$, before application of the solution to the sections, as a control for binding specificity. Incubation of $\mathrm{ABC}$ with the tissue sections alone served as a nonspecific negative control. The blocking sugars used were: $\alpha$-D-methyl-mannose for Concanavalia ensifor- mis and Lens culinaris agglutinins; lactose for Ricinus communis agglutinin-I, Griffonia simplicifolia agglutinin-I, and Arachis hypogea agglutinin; $\alpha$-L-fucose for Ulex europaeus agglutinin-I; D-N-acetyl-glucosamine for Phytolacca americana, Triticum vulgaris and Lycopersicon esculentum agglutinins; and $\alpha-\mathrm{D}-\mathrm{N}$ acetyl-galactosamine for Dolichos biflorus and Glycine max agglutinins.

Tissue sections were finally counterstained with hematoxylin.

For electron microscopic studies, part of the same kidneys fixed in formalin were cut into 1 to $2 \mathrm{~mm}^{3}$, fixed in $2.5 \%$ glutaraldehyde buffered with $0.2 \mathrm{M}$ sodium cacodylate ( $\mathrm{pH}$ 7.4). They were post-fixed in $1 \%$ osmium tetroxide in sodium cacodylate buffer $0.1 \mathrm{M}$ for $2 \mathrm{~h}$ at $20^{\circ} \mathrm{C}$ and dehydrated in a graded ethanol series. Specimens were then stained en bloc with a $3 \%$ solution of uranyl acetate in absolute alcohol and embedded in a mixture of Epon-812/Araldite. Thick sections $(1 \mu \mathrm{m})$ were stained with toluidine blue. Thin sections were cut on a Reichert-Jung Ultracut E (Reichert-Jung, Wien, Austria), stained with uranyl acetate and lead citrate, and observed with a Zeiss EM 109 with trans-fiber-optic photography (Carl Zeiss, Oberkochem, Germany).

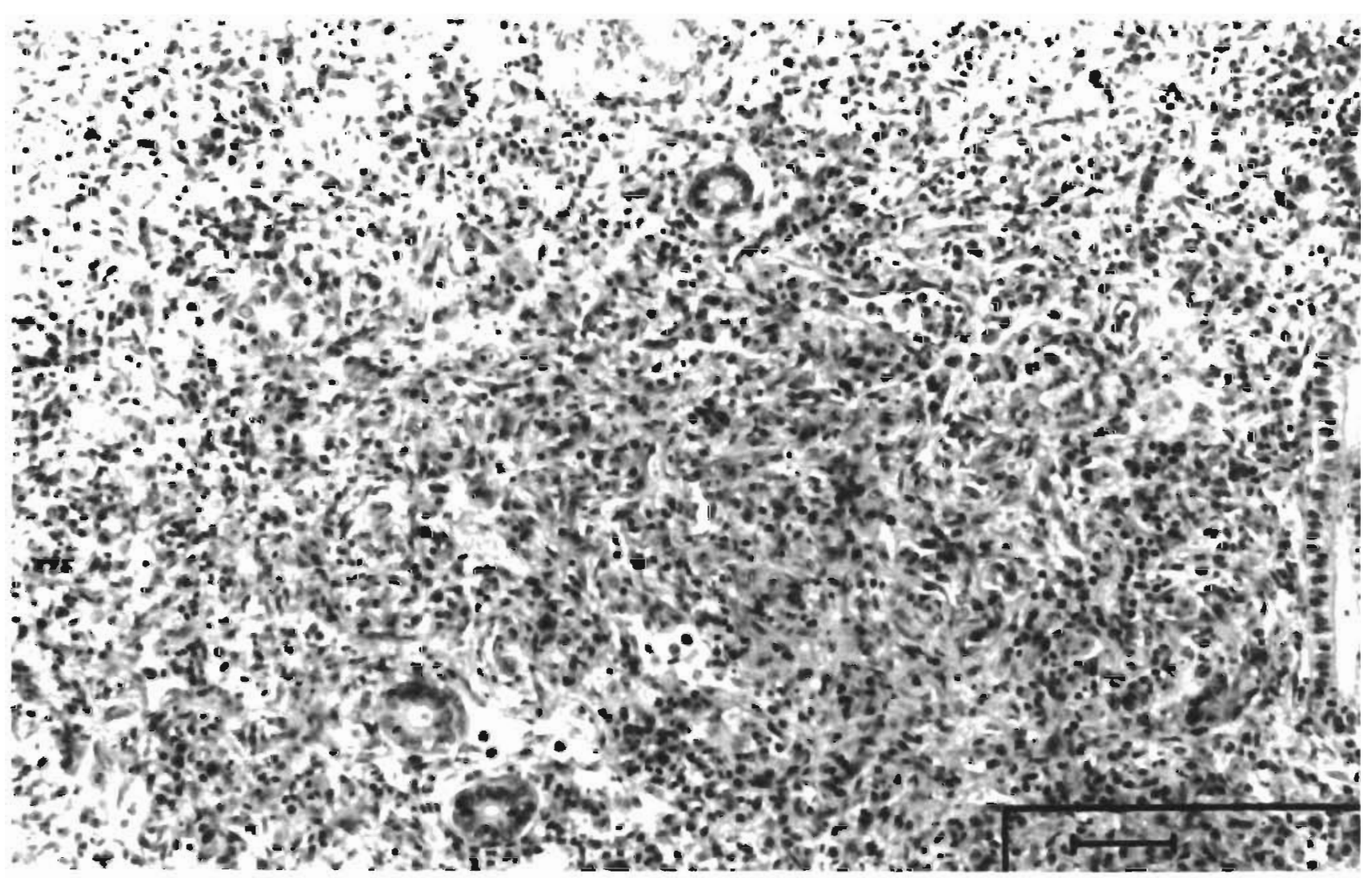

Fig. 1 Oncorhynchus mykiss. Photomicrograph from kidney of rainbow trout with PKD. H \& $E_{;}$bar $=50 \mu \mathrm{m}$. Typical granulomatous nephritis with loss of tubules and glomeruli are evident. At this magnification the PKX cells are not readily seen 


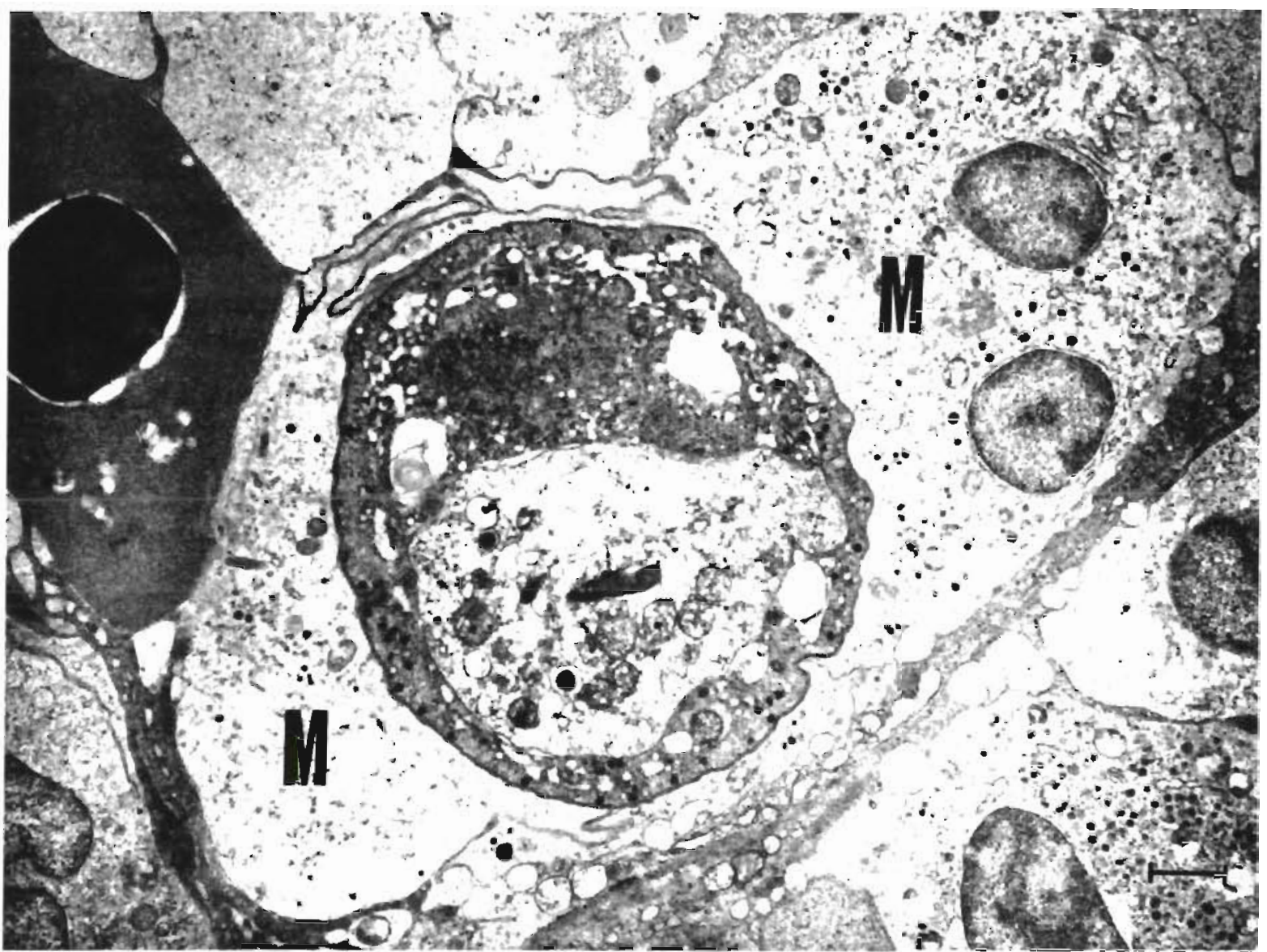

Fig. 2. Oncorhynchus mykiss. Electron micrograph from kidney of trout affected by PKD. Interstitial PKX cell surrounded by 2 macrophages $(\mathrm{M})$. Bar $=1.6 \mu \mathrm{m}$

\section{RESULTS}

\section{Light microscopy findings}

The light microscopic observations revealed the characteristic diffuse interstitial granulomatous nephritis associated with loss of the kidney tubules and glomeruli (Fig. 1). Typically, PKX cells were less eosinophilic than surrounding inflammatory cells and were localized in the interstitium and between tubular epithelial cells. Some intraluminal forms were also detected. No histologically detectable lesions were found in control kidneys.

\section{Electron microscopy findings}

Electron microscopic observations revealed the presence of PKX in all the kidneys affected by the granulomatous reaction. No PKX were detected in normal control kidneys.

Many primary cells with secondary and tertiary daughter cells were observed in between tubular epithelial cells and in the interstitium (Fig. 2). They always contained the haplosporosome-like electron dense granules, cisternae or sacculi of endoplasmic reticulum, and large, electron-dense and osmiophilic secondary lysosomes. In many cases the cytoplasm of primary and daughter cells showed mitochondria with fragmented cristae, shrunk and fragmented cytoplasmic membranes, and large empty cytoplasmic spaces. Daughter cells never contained the haplosporosomelike granules.

Some uninucleated intraluminal forms of PKX detected in a few tubules, were similar to the internal daughter cells seen in the interstitium and in the tubular epithelium.

In the interstitium the parasites were usually surrounded by macrophages (Fig. 2). The latter were identified according to the morphology of the nucleus with marginally dispersed chromatin, the presence of heterogeneously sized electron-dense lysosomes in a large cytoplasm, and a prominent Golgi apparatus (Roberts 1989). Macrophages were most often elon- 
Table 2. Lectin binding patterns found with PKX primary and daughter cells, macrophages, lymphocytes, and tubular epithelial cells. Intensity of staining: +++ , intense,++ moderate; + , weak $;+-$, inconsistent; - , none

\begin{tabular}{|c|c|c|c|c|c|}
\hline Lectins & $\begin{array}{c}\text { PKX } \\
\text { primary cell }\end{array}$ & $\begin{array}{c}\text { PKX } \\
\text { daughter cell }\end{array}$ & Lymphocyte & Macrophage & $\begin{array}{l}\text { Renal } \\
\text { tubules }\end{array}$ \\
\hline PNA & + & - & $-1-$ & +++ & +++ \\
\hline Con-A & $++t$ & + & ++ & + & ++ \\
\hline $\mathrm{DBA}$ & $+1-$ & - & - & - & - \\
\hline SBA & $+1-$ & - & - & $+1-$ & ++ \\
\hline GS-I & +++ & ++ & - & - & +++ \\
\hline LEA & ++ & + & ++ & +++ & +++ \\
\hline LCA & + & - & ++ & +++ & +++ \\
\hline PWM & +++ & ++ & +++ & +++ & ++ \\
\hline RCA-I & +++ & + & +++ & +++ & +++ \\
\hline WGA & + & - & $+t$ & +++ & +++ \\
\hline UEA-I & - & - & - & - & - \\
\hline
\end{tabular}

gated, crescent-shaped and closely adherent to the cell surface of parasites. However, some macrophages were seen in the tubular epithelium between epithelial cells. Lymphocytes were also detected in interstitial spaces but never adjacent to PKX. Finally, some melanomacrophages were seen in the interstitium whereas granulocytes were scattered throughout the hemopoietic tissue.

\section{Lectin histochemistry}

Except Ulex europaeus agglutinin-I, all the lectin used displayed a specific binding pattern in control and PKD-affected kidneys. The lectin staining pattern is summarized in Table 2. The lectin binding patterns considered were those observed with PKX primary and daughter cells, macrophages, lymphocytes, and renal tubular epithelial cells.

Concanavalia ensiformis (Con-A), Lycopersicon esculentum (LEA), Lens culinaris (LCA), Phytolacca americana (PWM), Ricinus communis (RCA-I) and Triticum vulgaris (WGA) agglutinins stained moderately to strongly the cytoplasm of PKX primary cells, and the macrophages, lymphocytes, and all tubular epithelial cells (Figs. 3 \& 4). However, PWM bound to the luminal surface of only some tubules per sections, leaving other tubules unstained (Fig. 6). PKX-DCs and intraluminal forms were less intensely stained than PKX-PCs with Con-A, LEA, PWM, and RCA-I, and did not express lectin receptors for LCA and WGA.

Arachis hypogea agglutinin (PNA) bound strongly to the cytoplasm of macrophages, and tubular epithelial cells whereas a weak reaction was present in the cytoplasm of PKX primary cells (Fig. 5). Because it bound weakly only to some lymphocytes, the staining of PNA on lymphocytes was considered inconsistent.
Griffonia simplicifolia agglutinin-I (GS-I) bound strongly to the cytoplasm of all PKX primary cells located in the interstitium, between tubular epithelial cells, and in glomeruli (Figs. 6 \& 7). Moderate reaction was present in the cytoplasm of PKX daughter cells and intraluminal parasites, whereas an intense linear staining was detected at the luminal surface of some tubular epithelial cells.

Dolichos biflorus (DBA) and Glycine max (SBA) agglutinins stained weakly the cytoplasm of some primary PKX without any apparent differences in the parasite morphology or location (Fig. 8). SBA stained also some macrophages and the luminal surface of certain tubules.

Staining of all lectins was inhibited after the incubation of each with their specific sugars.

Figs. 3 to 8 (following 3 pages). Oncorhynchus mykiss. Photomicrographs from kidney of trout with PKD and stained by different lectins. Fig. 3. Lens culinaris agglutinin; bar $=16 \mu \mathrm{m}$. Inflammatory and tubular epithelial cells are strongly stained whereas PKX primary cells (arrows) are weakly positive. Fig. 4. Phytolacca americana agglutinin; bar $=16 \mu \mathrm{m}$. In the interstitium inflammatory and PKX cells are strongly stained. In one tubule a PKX cell (arrow) can be observed. Note that these tubules are not stained. Fig. 5. Arachis hypogea agglutinin; bar $=16 \mu \mathrm{m}$. PKX primary cells are weakly stained whereas the surrounding macrophages (arrows) are strongly labelled. Fig. 6. Griffonia simplicifolia agglutinin-I (GS-I); bar $=100 \mu \mathrm{m}$. At this magnification PKX cells appear as black spots scattered throughout the granulomatous reaction. Fig. 7. GS-I; bar $=16 \mu \mathrm{m}$. Some interstitial and one intraluminal (arrow) PKX cells can be observed. Note that daughter cells and the intraluminal form are less intensely stained than PKX primary cells. The tubule at the right (star) shows strong luminal surface staining. Fig. 8. Glycine max agglutinin; bar = $16 \mu \mathrm{m}$. Some weakly stained macrophages (arrows) and unstained PKX cells are present. A strong luminal binding can be observed in one tubule (star). Melanin pigment as detected in melanomacrophages (arrowheads) 


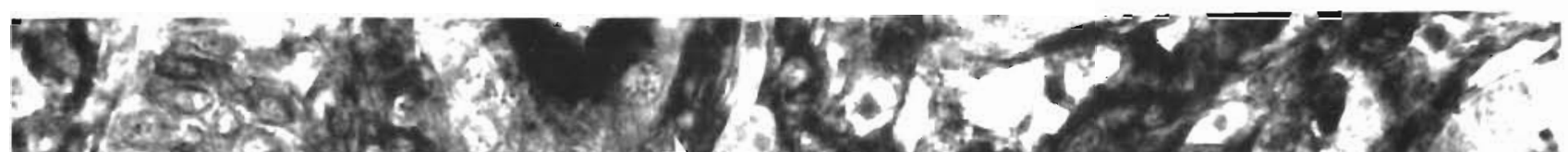

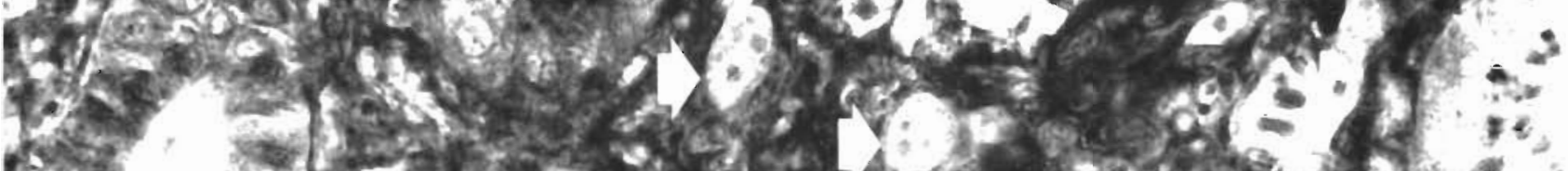

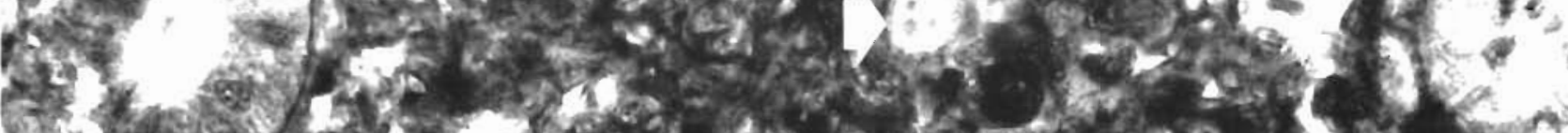

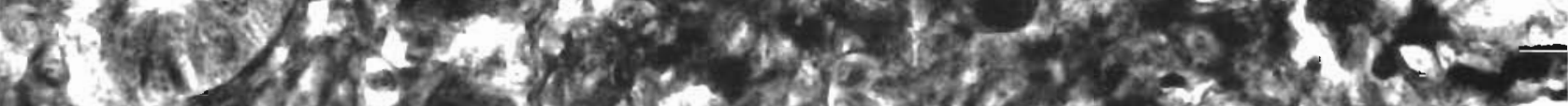

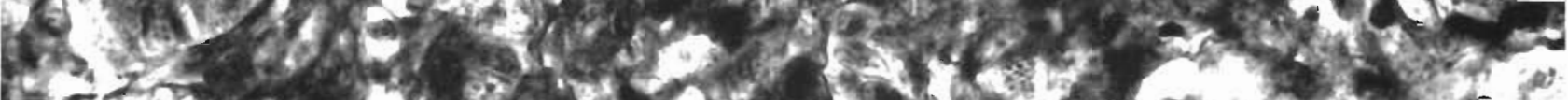

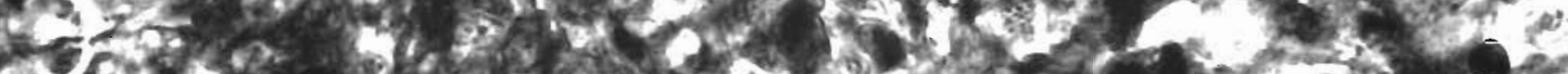

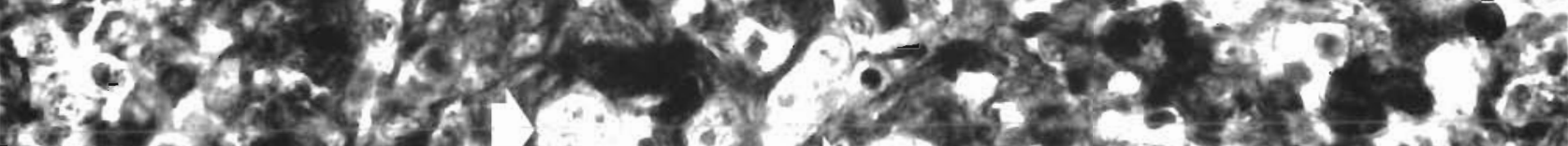

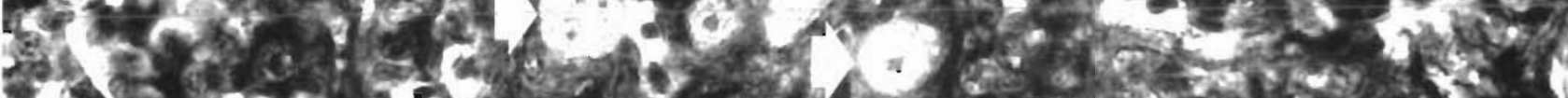

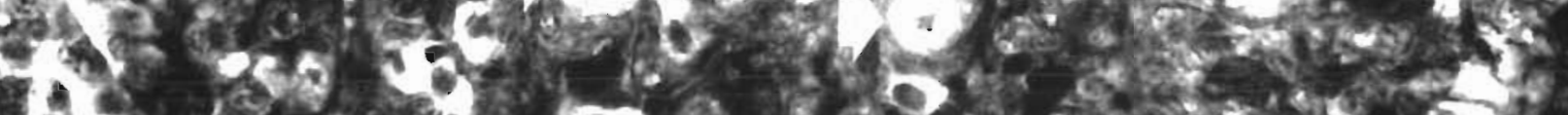

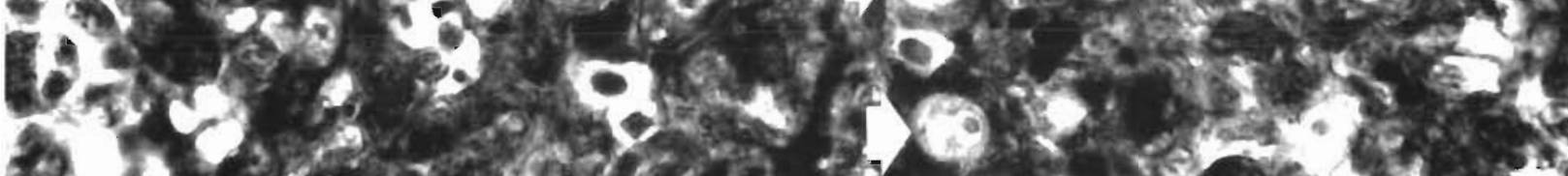

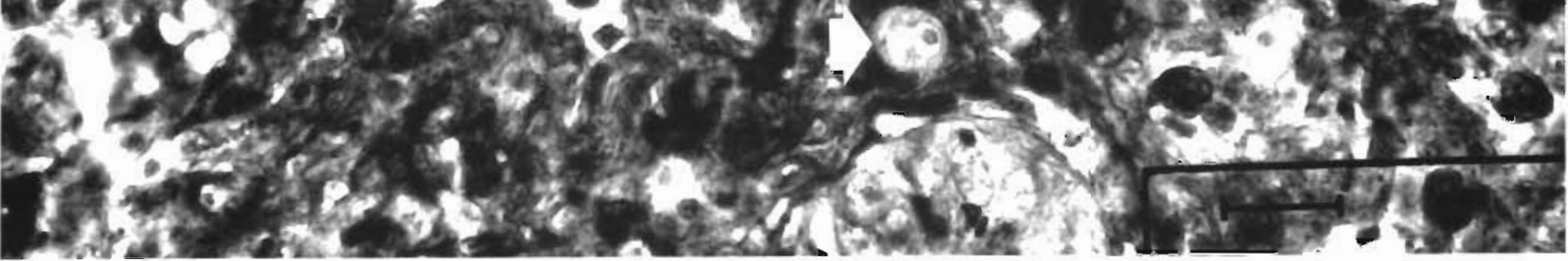

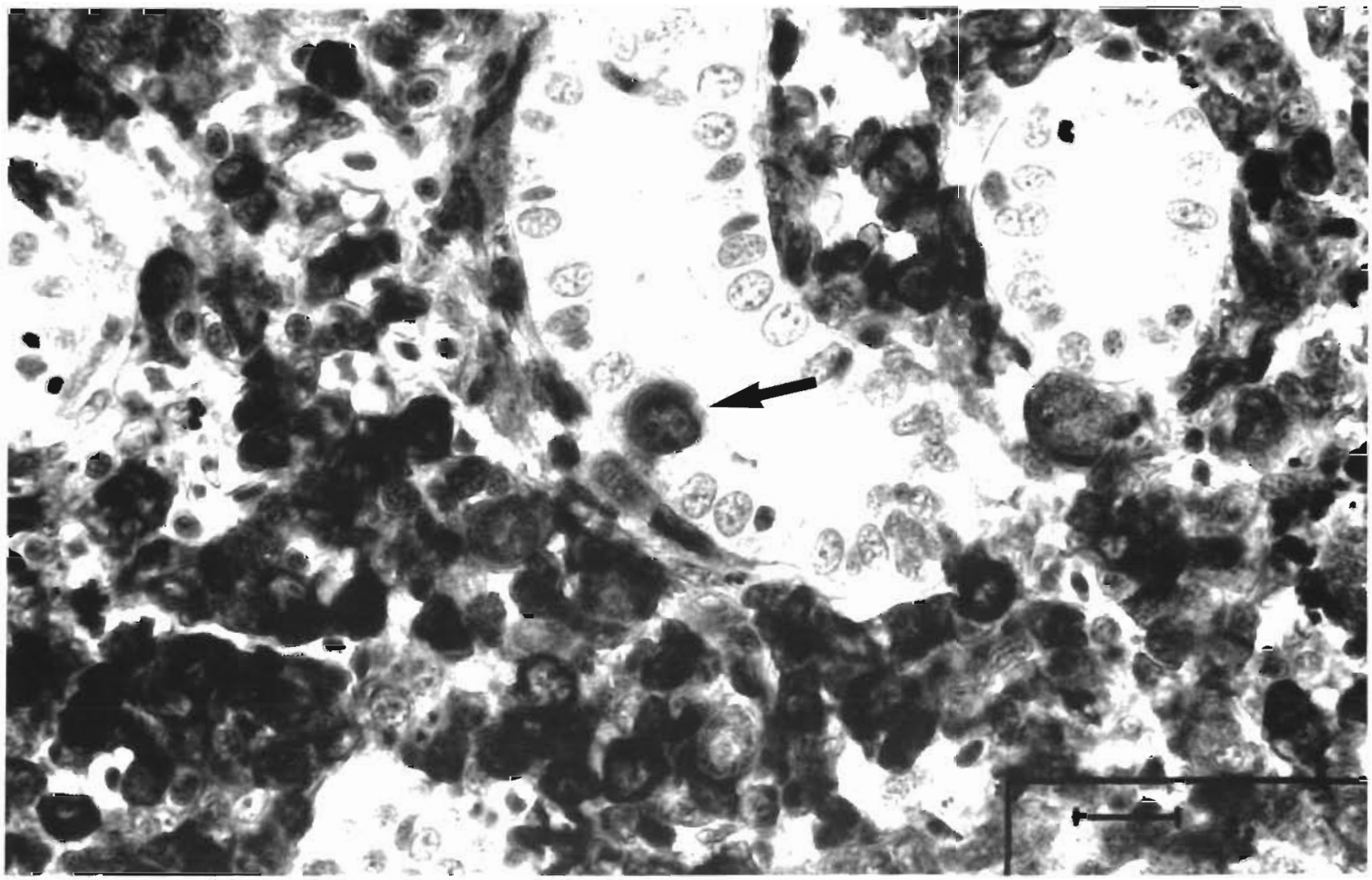




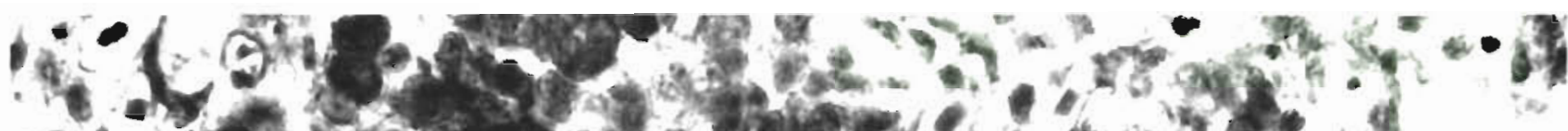

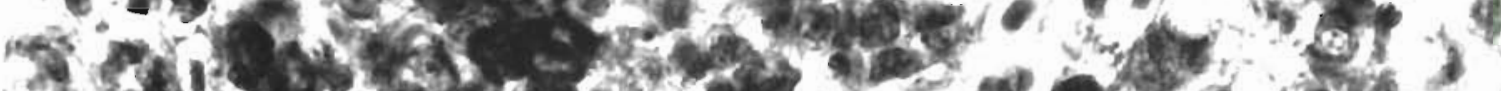

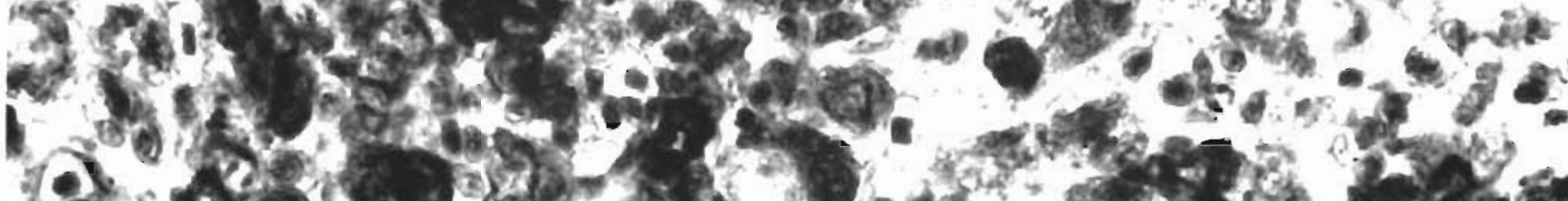

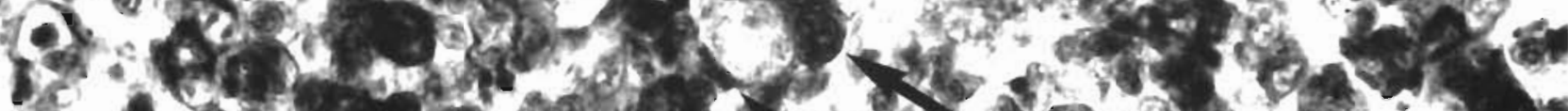
4.

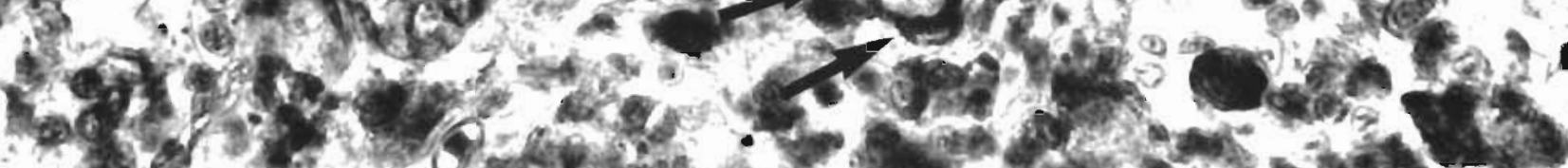

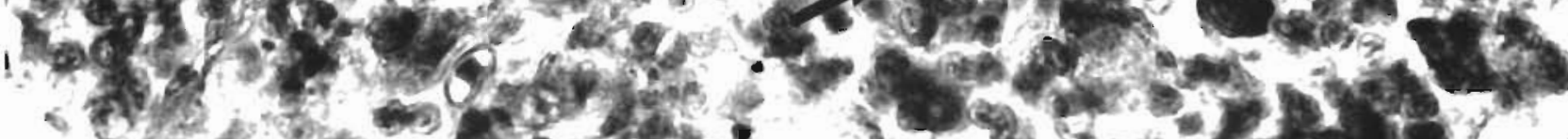

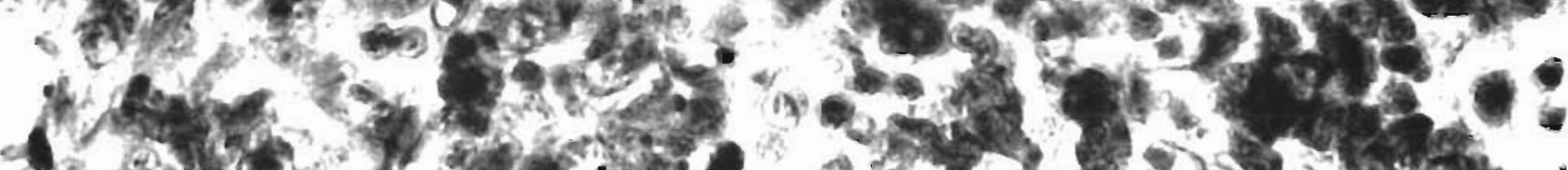
1. Fin,

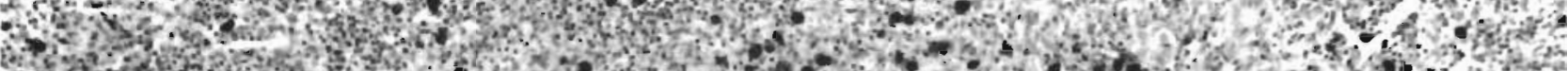

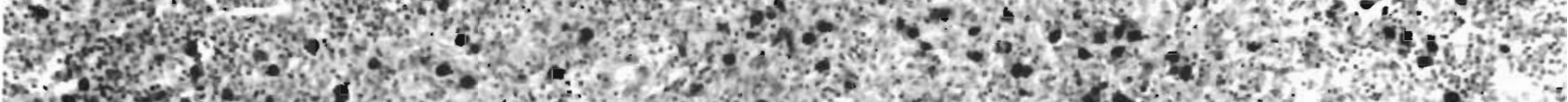

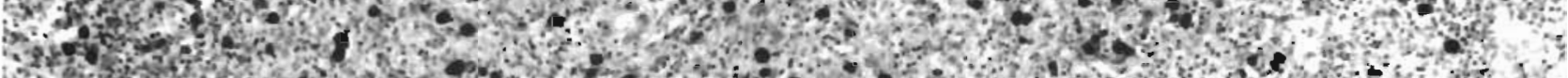

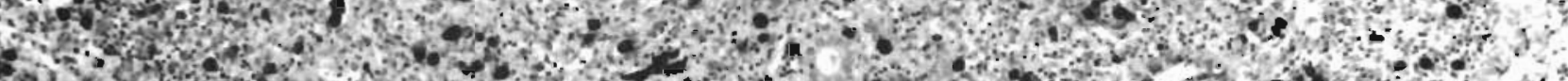

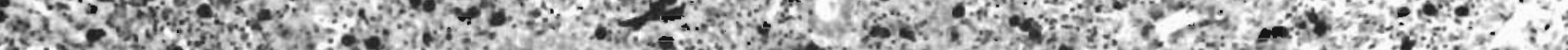

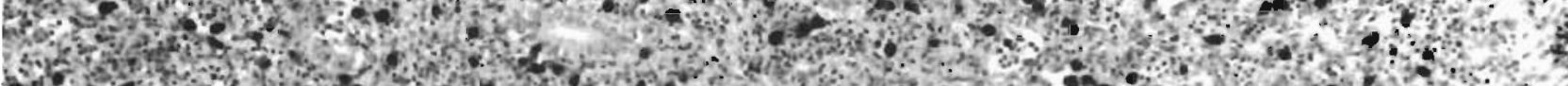

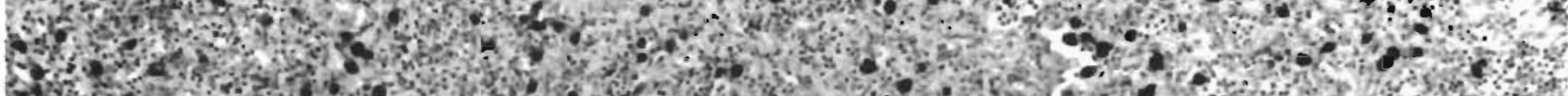
7.

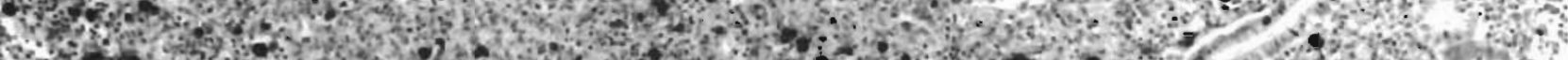

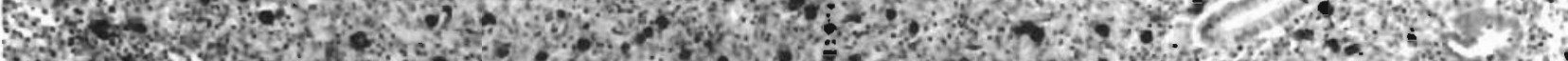

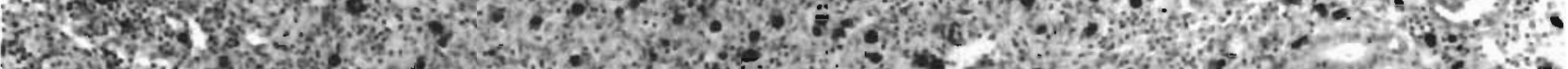

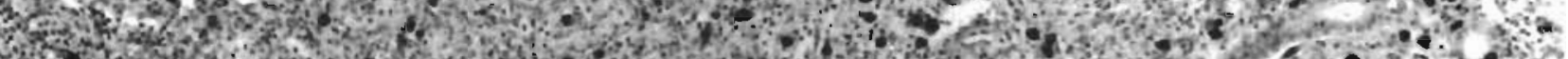

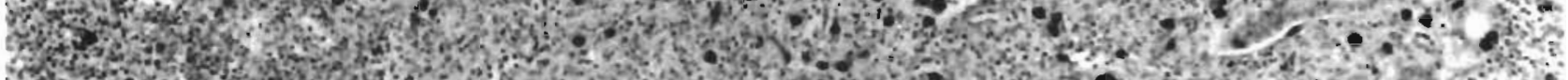

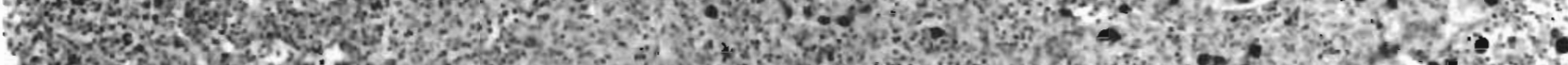

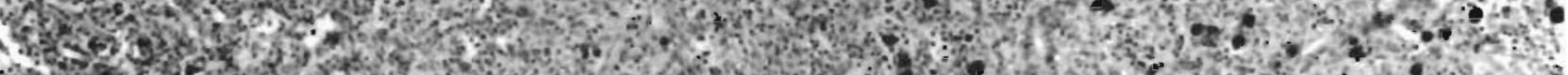

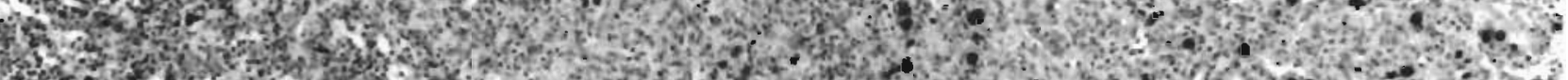

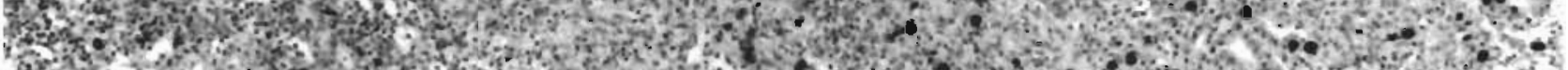

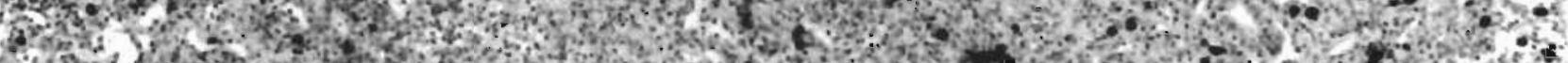

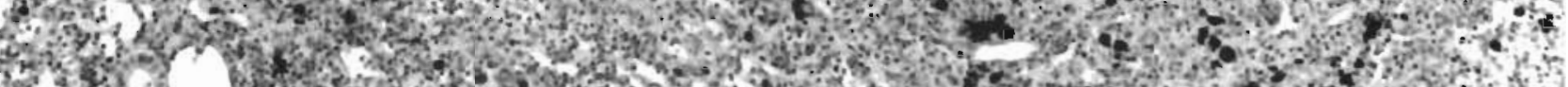

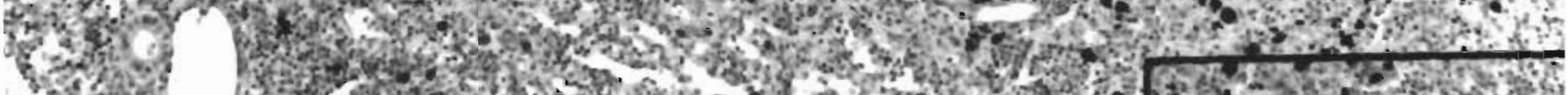

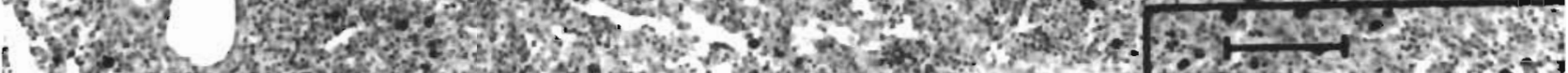

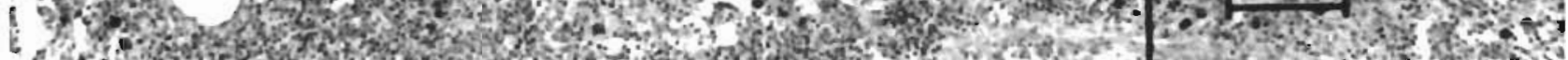




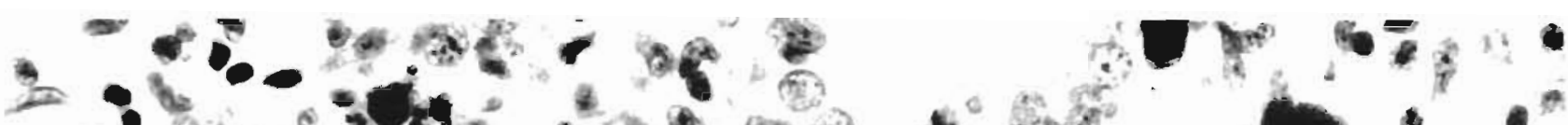

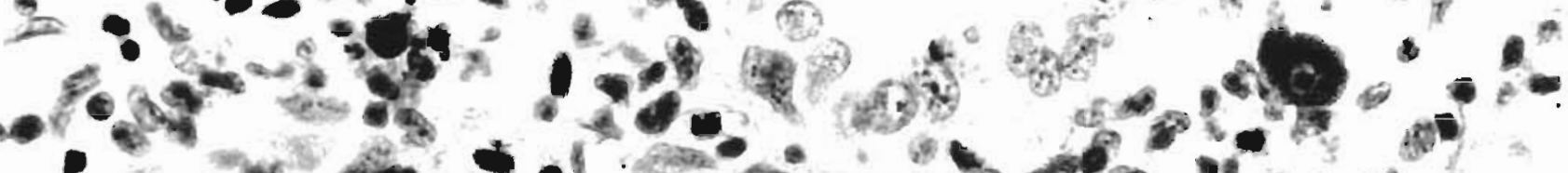

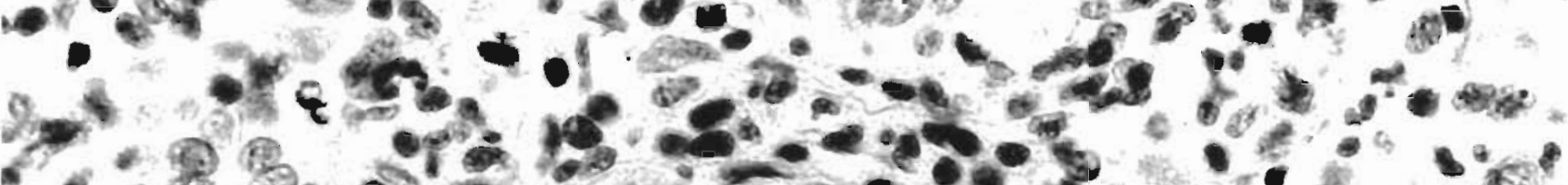

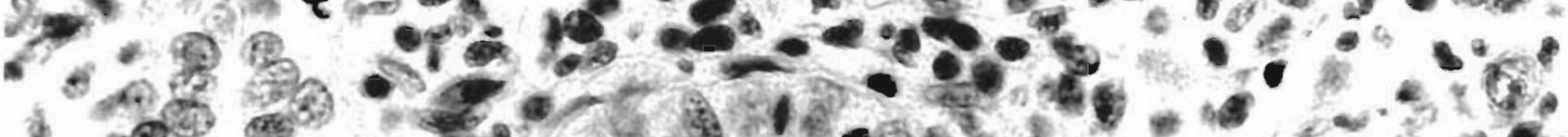

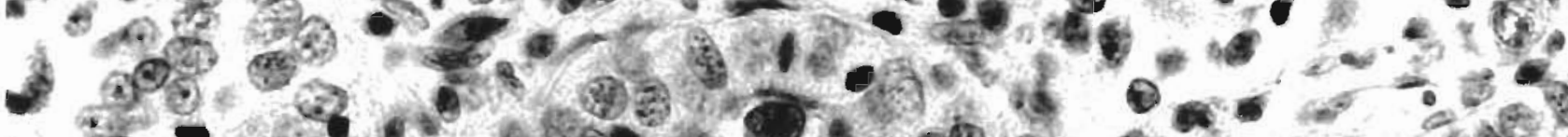

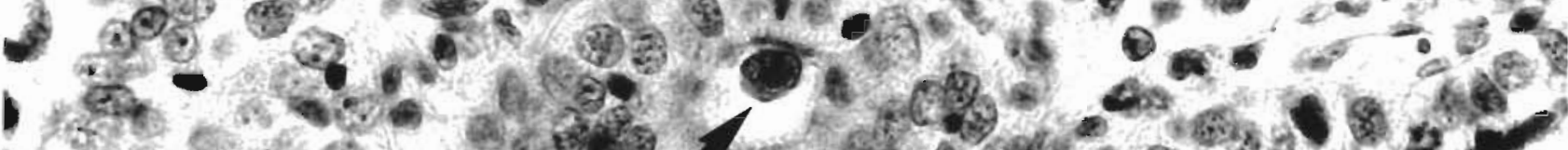

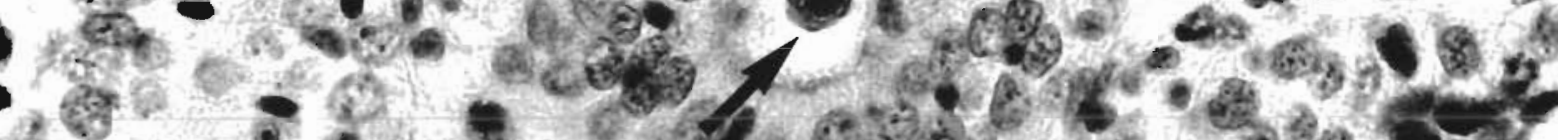

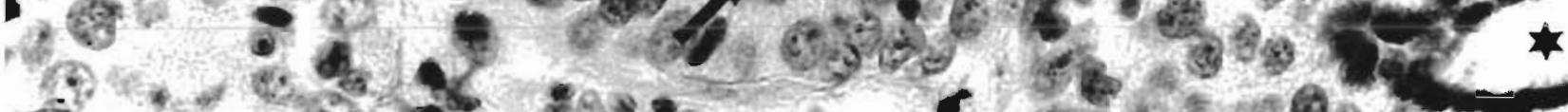

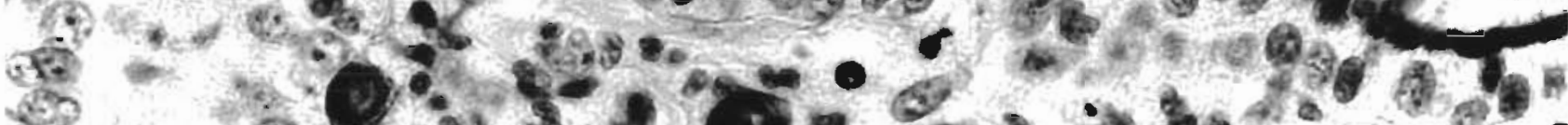

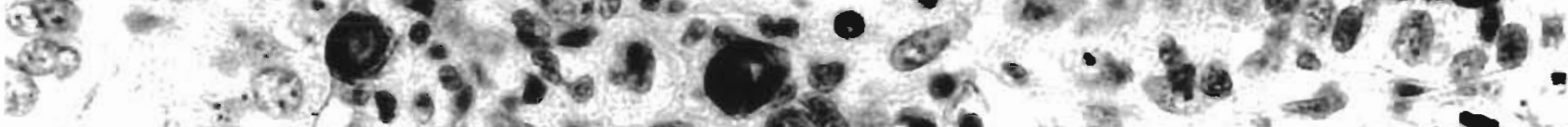

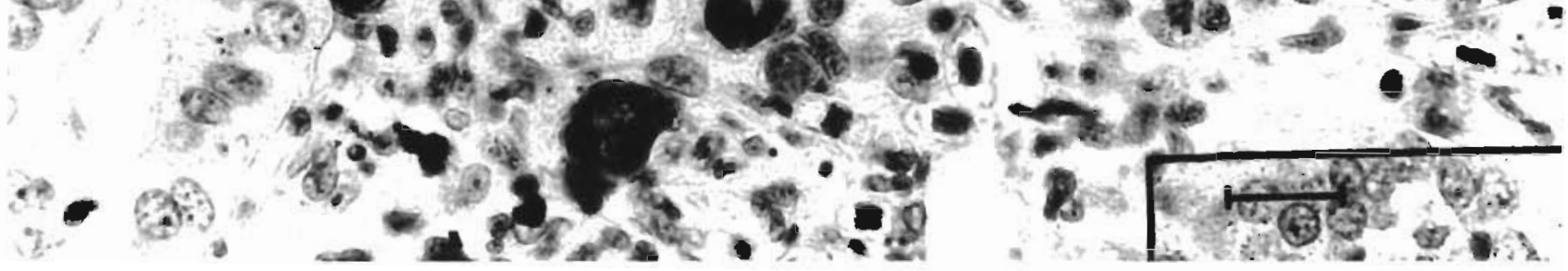

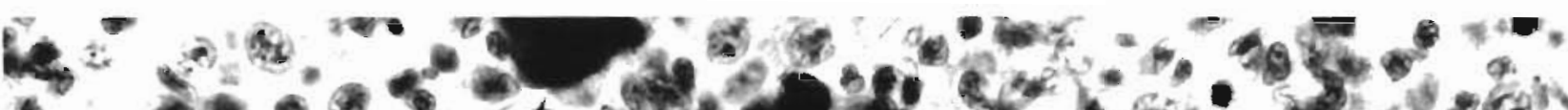

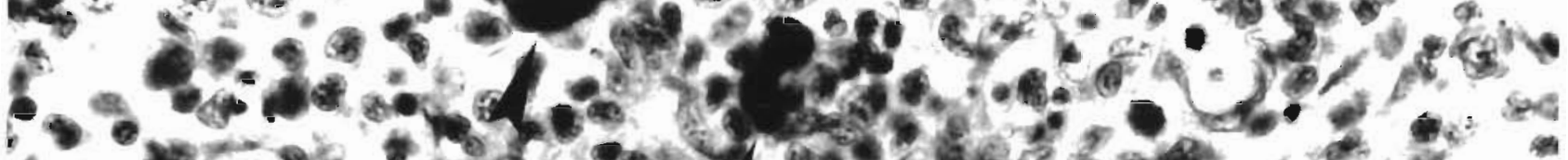

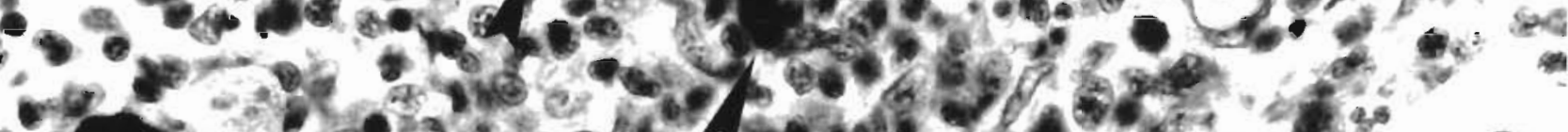

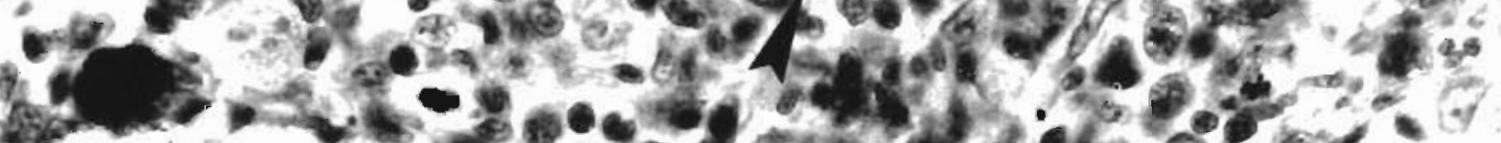
17\%



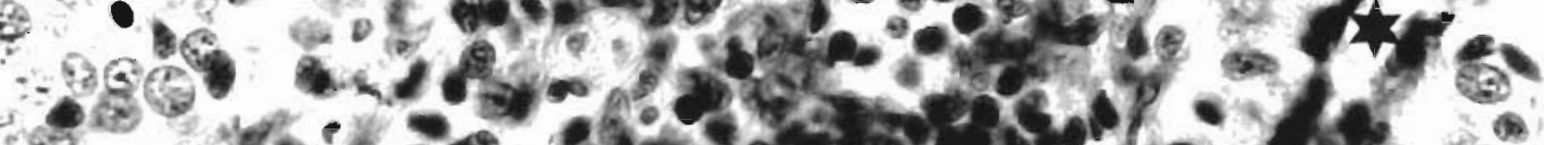

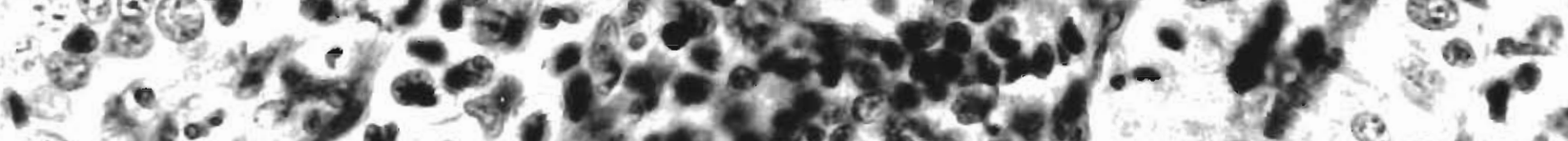

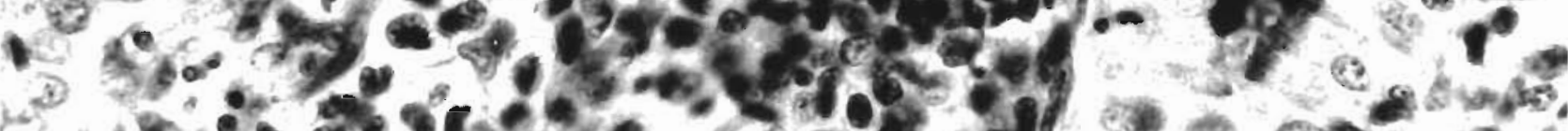

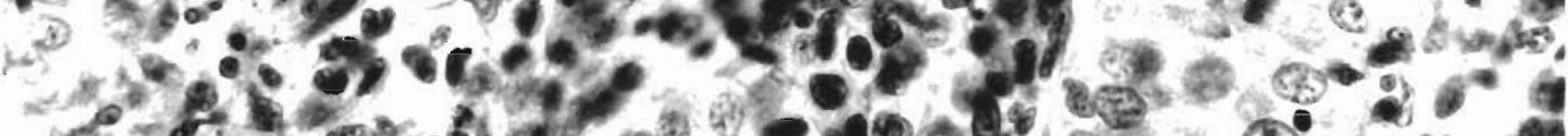

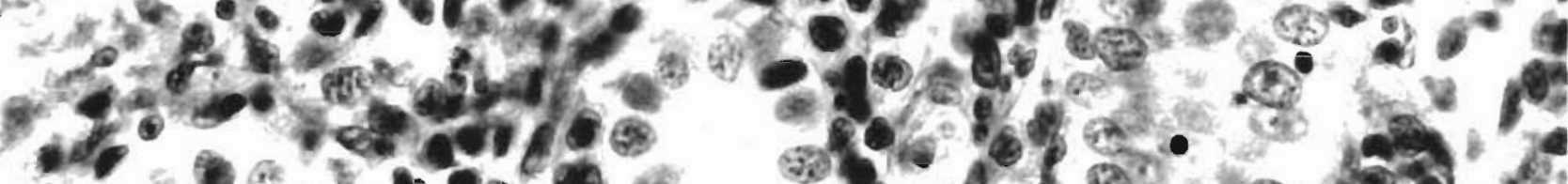

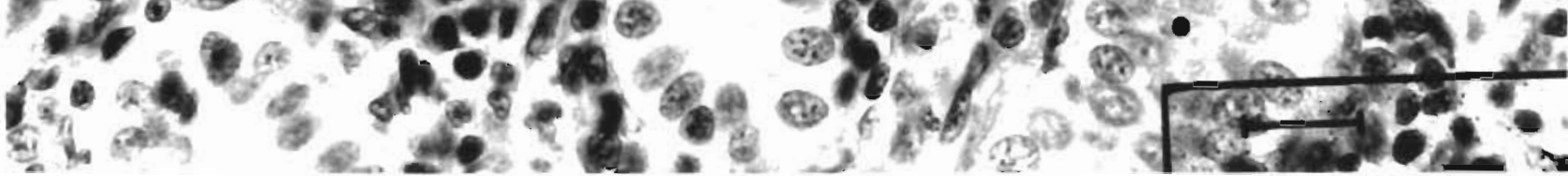
Fig. 8 


\section{DISCUSSION}

Each lectin used in this study, except Ulex europaeus agglutinin-I (UEA-I), had a specific binding distribution on PKX, inflammatory and tubular epithelial cells.

The lectin bindings to PKX primary cells revealed the presence of $\alpha$-D-mannose, $\alpha$ - and $\beta$-galactose, $\mathrm{N}$-acetyl-glucosamine oligomers, $\mathrm{N}$-acetyl-galactosamine, galactose- $\beta$-(1-3)-N-acetyl-galactosamine, and sialic acid residues (Etzler \& Kabat 1970, Nicolson 1974, Pereira et al. 1974, 1976, Goldstein \& Hayes 1978 , Pereira et al. 1978, Monsigny et al. 1980, Debray et al. 1981, Nachbar \& Oppenheimer 1982). Compared to PKX primary cells, Concanavalia ensiformis (Con-A), Griffonia simplicifolia (GS-I), Lycopersicon esculentum (LEA), and Phytolacca americana (PWM) agglutinins stained PKX daughter cells less intensely. The latter stages of PKX were not stained with Arachis hypogea (PNA), Dolichos biflorus (DBA), Glycine max (SBA), Lens culinaris (LCA), and Triticum vulgaris (WGA) agglutinins. These observations reveal differences in glycoconjugate contents between primary and secondary PKX cells and provide preliminary data on the carbohydrate components of these cells. This may give new insights on their chemical composition and help to determine the precise classification of this protozoan (Lis \& Sharon 1984). The glycoconjugate composition of PKX could also be important in understanding pathogenetic mechanisms such as the stage-dependent adhesive properties, antigenic switching, and the impairment of the host immune system (Mahmoud 1989).

Two out of the 11 lectins used in our study appear to be useful for the histological detection of PKX and for the evaluation of the inflammatory response of infected rainbow trout.

The lectin PNA, specific for the disaccharide galactose- $\beta$-(1-3)-N-acetyl-galactosamine, stained PKX primary cells and lymphocytes in the renal interstitium very weakly but the surrounding macrophages strongly. This lectin also stained granulocytes intensely but, since electron microscopic observations revealed rarely granulocytes among the interstitial inflammatory cells, the strongly positive cells located in the interstitium and frequently surrounding PKX are believed to be macrophages.

The macrophage is the most important cell type for cellular reaction against infectious and noninfectious foreign agents (Corbel 1975). The macrophage is also the predominant cell type involved in the defensive reaction to $\mathrm{PKX}$ and is believed to play an essential role in interrupting the development of PKX and in elimination of the parasite from the host (MacConnell et al. 1988). Thus, the lectin PNA could be an important tool to evaluate the macrophage reaction during $\mathrm{PKD}$ and other infections of fishes where they play a crucial role in host cellular defense mechanisms.

Lectin receptors for Con-A, LEA, LCA, PWM, RCA-I and WGA, were present in PKX, inflammatory and tubular epithelial cells. Because none of these lectin receptors was located exclusively to one specific structure, these lectins are not useful for the identification of PKX or for evaluation of the host inflammatory response. In contrast, the lectin GS-I, specific for $\alpha$ galactose, stained the cytoplasm of PKX primary cells in interstitium, glomeruli, between tubular epithelial cells intensely, and PKX daughter cells and intraluminal parasites moderately. An intense linear reaction was also present at the luminal surface of some tubules. A nearly identical staining pattern has been reported in an immunohistochemical study on kidneys of PKD infected rainbow trout using a polyclonal anti-PKX rabbit serum (Rafferty 1986). Later the same technique was used to differentiate PKX from Sphaerophora sp. in brown trout (Rafferty \& Mulcahy 1988).

It is well known that the carbohydrate components of glycoproteins and glycolipids can occur as antigenic determinants (Feizi 1985, Feizi \& Child 1987). It seems therefore possible that the polyclonal anti-PKX serum and biotinylated GS-I recognize the same carbohydrate antigen/receptor or closely related structures present on both PKX and luminal surface of epithelial tubular cells. Since GS-I bound to the surface of tubular epitheLial cells also in control kidney, the hypothesis of an accumulation of residual primary cells components in the tubular epithelium during the release of secondary cells into the lumen should be ruled out. The results obtained in our study and those reported by Rafferty (1986) indicate that PKX and the luminal surface of tubular epithelial cells share the same antigen/receptor.

To our knowledge, this is the first report of a specific histochemical staining method for PKX protozoan. This elective, relatively inexpensive and commercially available method for PKX staining may be used in quantitative determination at light microscope level such as the efficiency of therapeutic trials against PKD; furthermore, this lectin can be employed to detect the protozoans when they are in low number, and, possibly, to recognize forms of the parasite presently not well known, such as the early infective stages. Finally, it is noteworthy that PKX daughter cells and intraluminal forms showed the same staining intensity for GS-I. According to the hypotheses that the interstitial form of PKX and the intraluminal myxosporeans belong to the same organism (Kent \& Hedrick 1986), our data suggest an origin of intraluminal form from PKX daughter cells.

The lectins DBA, specific for $\alpha-D-N$-acetyl-galactosamine residues, and SBA, specific for $\mathrm{D}-\mathrm{N}$-acetyl- 
galactosamine and D-galactose, stained only certain PKX primary cells in a section. Apparently, there were no differences in morphology and location between DBA-positive and DBA-negative PKX cells. However, at present we cannot exclude that this variation in DBA and SBA binding pattern is related to different carbohydrate composition of various developmental stages of PKX primary cells. Further histochemical studies at the electron microscopic level might clarify this point.

Finally, the difference observed in the staining distribution of some lectins (i.e. GS-I, PWM, and SBA) between different nephron tracts point out that the physiologic sugars compartmentalization already reported in some mammalian species (Holthöfer 1983, Casiagnaro et ai. 1987, Castagnaro 1990) occurs also in fish kidney.

Acknowledgements. Dr M. Marin is recipient of a fellowship 'Formación de Postgrado en el Extranjero' from Ministerio de Educación y Ciencia of Spain.

\section{LITERATURE CITED}

Alroy, J., Ucci, A. A., Pereira, M. E. A. (1984). Lectins: histochemical probes for specific carbohydrate residues. In: De Lellis, R. A. (ed.) Advances in immunohistochemistry. Masson Inc., New York, p. 66-88

Castagnaro, M., Alroy, J., Ucci, A. A., Glew, R. H. (1987). Lectin histochemistry and ultrastructure of cat kidneys from six different storage diseases. Virchows Arch. B 54: $16-26$

Castagnaro, M. (1990). Lectin histochemistry of rabbit nephron. Biol. Struct. Morphogen 3: 21-26

Clifton-Hadley, R., Bucke, D., Richards, R. H. (1984). Proliferative kidney disease of salmonid fish: a review. J. Fish Dis. 7: 363-377

Clifton-Hadley, R. S., Bucke, D., Richards, R. H. (1987). A study of the sequential clinical and pathological changes during proliferative kidney disease in rainbow trout, Salmo gairdneri Richardson. J. Fish Dis. 10: 335-352

Clifton-Hadley, R. S., Richards, R. H., Bucke, D. (1985). The sequential pathological changes in proliferative kidney disease. In: Ellis A. E. (ed.) Fish and shellfish pathology. Academic Press, London, p. 359-367

Corbel, M. J. (1975). The immune response in fish: a review. J. Fish Biol. 7: 539-563

Cushion, M. T., DeStefano, J. A., Walzer, P. D. (1988). Pneumocystis carinil: surface reactive carbohydrates detected by lectin probes. Exp. Parasitol. 67: 137-147

Damjanov, I. (1987). Lectin histochemistry and cytochemistry. Lab. Invest. $57 \cdot 5-20$

Danguy, A., Kiss, R., Pasteels, J.-L. (1988). Lectins in histochemistry. A survey. Biol. Struct. Morphogen, 1 93-106

Debray, H., Decout, D., Strecker, G., Spike, G., Montreuil, J (1981). Specificity of twelve lectins towards oligosaccharides and glycopeptides related to $\mathrm{N}$-glycoproteins. Eur. J. Biochem. 117: 41-55

Etzler, M. E., Kabat, E. A. (1970). Purification and characterization of a lectin (plant agglutinin) with blood group $A$ specificity from Dolichos biflorus. Biochem. 9: 869-877
Feizi, $T$ (1985). Demonstration by monoclonal antibodies that carbohydrate structures of glycoproteins and glycolipids are onco-developmental antigens. Nature, Lond. 314:5357

Feizi, T., Childs, R. A. (1987). Carbohydrates as antigenic determinants of glycoproteins. Biochem. J. 245: 1-11

Ferguson, H. V., Needham, E. A. (1978). Proliferative kidney disease in rainbow trout Salmo gairdneri Richardson. J. Fish Dis. 1. 91-108

Frydecka, I., Slesak, B., Benczur, M. (1987). Heterogeneity of human natural killer cells with respect to lectin-binding ability. J. natn. Cancer Inst. 78: 1145-1148

Ghittino, C. (1984). Studi sull'iperplasia emopoietica parassitaria della trota d'allevamento. Rivista Italiana di Piscicoltura e Ittiopatologia XIX: 133-147

Ghittino, P., Andruetto, S., Vigliani, E. (1977). L'amebiasi della trota iricea d'Allevamento. Riv. Ital. Piscic. Ittiopatol. 12: 74-89

Goldstein, I. J., Hayes, C. E. (1978). The lectins: the carbohydrate bindiny proieins of plants and animais. Adv. Carbohydr. Chem. Biochem. 35: 127-340

Goldstein, I. J., Hughes, R. C., Monsigny, M., Osawa, T., Sharon, N. (1980). What should be called a lectin? Nature, Lond. 285: 66

Hedrick, R. P., Kent, M. L., Foott, M.S., Rosemark, R., Manzer, D. (1985). Proliferative kidney disease among salmonid fish in California, USA; a second look. Bull. Eur. Ass. Fish Pathol. 5: 36-38

Hedrick, R. P., Kent, M. L., Rosemark, R., Manzer, D. (1984) Proliferative kidney disease (PKD) in Pacific salmon and steelhead trout. J. World Maricult. Soc. 15: 318--325

Hedrick, R. P., Kent, M. L., Smith, C. E. (1986). Proliferative kidney disease in salmonid fishes. Fish Dis. Leaflet No. 74 , United States Dept. Interior. Fish \& Wildlife Service, Washington, D.C., 1-19

Hedrick, R. P., Kent, M. L., Toth, R. J., Morisson, J. K. (1987). Fish infected with Sphaerospora spp. Thelohan (Myxosporea) from waters enzootic for proliferative kidney disease of salmonids. J. Protozool. 35: 13-18

Heegaard, P. M. H., Müller, K. (1988). Lectins and the immune system. EOS J. Immunol. Immunopharmacol. VIII: 239-247

Holthöfer, H. (1983). Lectin binding sites in kidney. A comparative study of 14 animal species. J. Histochem. Cytochem. 31: 531-537

Howard, D. R., Batsakis, J. G. (1982). Peanut agglutinin: a new marker for tissue histiocytes. Am. J. Clin. Pathol. 77 $401-408$

Kent, M. L., Hedrick, R. P. (1986). Development of the PKX myxosporean in rainbow trout Salmo gairdneri. Dis. aquat. Org. 1: 169-182

Klontz, G. W., Rourke, A. W., Eckblad, W. (1986). The immune response during proliferative kidney disease in rainbow trout: a case history. Vet. Immunol. Immunopathol. 12: 387-393

Leducq, R., Gabrion, J., Gabrion, C. (1988). Caractérisation des glycoconjués de surface et intracellulaires dans les formes larvaires d'Echinococcus multilocularis à l'aide de lectines. Comp. Rend. Soc. Biol. 182: 501-508

Lis, H., Sharon, N. (1984). Lectins: properties and applications to the study of complex carbohydrates in solution and on cell surfaces. In: Ginsburg, V., Robbins, P. W. (eds.) Biology of carbohydrates, Vol. II John Wiley \& Sons, New York, p. 1-85

MacConnell, E., Smith, C. E., Hedrick, R. P., Speer, C. A. (1988). Cellular inflammatory response of rainbow trout to the protozoan parasite that causes proliferative kidney disease. J. aquat. Anim. Health 1: 108-118 
Mahmoud, A. A. F. (1989). Parasitic protozoa and helmints: biological and immunological challenges. Science 246 : 1015-1022

deMiranda Santos, I. K. F., Pereira, M. E. A. (1984). Lectin discriminates between pathogenic and nonpathogenic South American trypanosomes. Am. J. Trop. Med. Hyg. 33: 839-844

Monsigny, M. Roche, A. C., Sene, C., Maget-Doma, R., Delmotte, F. (1980). Sugar-lectin interactions: how does wheat germ agglutinin bind sialoglycoconjugates? Eur. J. Biochem. 104: 147-153

Nachbar, M. S., Oppenheimer, J. D. (1982). Tomato ( $L$. esculentum) lectin. Methods Enzymol. 83: 363-368

Nagi, A. M., Babiuk, L. A. (1989). Peanut agglutinin (PNA) binding and stimulation of bovine intestinal and peripheral blood leucocytes. Vet. Immunol. Immunopathol. 22: 67--78

Nicolson, G. L. (1974). The interactions of lectins with animal cell surfaces. Int. Rev. Cytol. 39: 89-190

Pereira, M. E. A., Kabat, E. A., Lotan, R., Sharon, N. (1976) Immunochemical studies on the specificity of the peanut (Arachis hypogea) agglutinin. Carbohydr. Res. 51: $107-118$

Pereira, M. E. A., Kabat, E. A., Sharon, N. (1974) Immunochemical studies on the specificity of soybean agglutinin. Carbohydr. Res. 37: 89-102

Pereira, M. E. A., Kisailus, E. C., Gruezo, F., Kabat, E. A.

Responsible Subject Editor: W. Körting, Hannover, Germany
(1978). Immunochemical studies on the combining site of blood group $\mathrm{H}$-specific lectin from Ulex europaeus seeds. Arch. Biochem. Biophys. 185: 108-115

Plehn, M. (1924). Praktikum der Fischkrankheiten. E. Schweizerbart'sche Verlagsbuchhandlung, Stuttgart

Rafferty, M. D. (1986). A study of proliferative kidney disease in rainbow trout. $\mathrm{Ph}$. $\mathrm{D}$. thesis. National University of Ireland

Rafferty, M. D., Mulcahy, M. F. (1988). Is P. K. 'X' related to sphaerospora? Bull. Eur. Ass. Fish Pathol. 8: 47

Roberts, R. J. (1989). The anatomy and physiology of teleosts. In: Roberts, R. J, (ed.) Fish pathology. 2nd edn. Bailliére Tindall, London, p. 13-55

Seagrave, C. P., Bucke, D., Alderman, D. J. (1980). Ultrastructure of a haplosporean-like organism: the possible causative agent of proliferative kidney disease in rainbow trout. J. Fish Dis. 16: 453-459

Turnwald, G. H., McClure, J. J., Powell, M. D., Shao, K.-K. P. (1988). Peanut agglutinin as a surface marker for canine $T$ lymphocytes. Am. J. Vet. Res. 49: 2076-2080

Ward, H. P., Alroy, L., Lev, B., Keusch, G. T., Pereira, M. E. A (1985). Identification of chitin as structural component of Giardia cysts. Infect. Immun. 49: 629-634

Zelck, U., Becker, W. (1990). Lectin binding to cells of Schistosoma mansoni sporocysts and surrounding Biomphalaria glabrata tissue. J. Invert. Pathol. 55: 93-99

Manuscript first received: December 10, 1990

Revised version accepted: February 19, 1991 